\title{
LASER ABLATION OF NON-MUSCLE INVASIVE BLADDER TUMORS; ANY ADVANTAGE OVER STANDARD RESECTION PROSPECTIVE COMPARATIVE STUDY
}

\section{Saif El-Islam Mustafa Mohamed Awida*, Ahmed Tawfick Hassan, Ahmed Farouk Mahmoud Salim, and Hassan Sayed Shaker}

\begin{abstract}
Urology Department, Faculty of Medicine, Ain Shams University Corresponding Author: Saif El-Islam Mustafa Awida

Mobile (+2) 01093952334

E-mail:

dr-saifmostafa@hotmail.com

Received :7/6/2020

Accepted: 30/6/2020
\end{abstract}

Online ISSN: 2735-3540

\section{ABSTRACT}

Background: The choice of treatment modality in patients with Non muscle invasive bladder cancer $(N M I B C)$ is one of the most discussed issues in urology.

One of major problems in management of NMIBC in high recurrence and progression rates. In recent years, the laser has increasing role in different urological fields.

Aim of the Work: Evaluation of the value of adding LASER ablation of the tumor bed after resection of the non-muscle invasive transitional cell carcinoma of the urinary bladder.

Patients and Methods: 136 patients with non-muscle invasive bladder cancer randomly divided into two groups: Group 1 underwent Laser ablation of tumor bed after resection (Laser group) $(n=68)$, and Group 2 underwent conventional transurethral resection of bladder tumor (TURBT group) (n=68). Operation time, irrigation time, Catheterization time, postoperative hospital stay, Postoperative clot retention or any postoperative complications, and results after each follow up cystoscopy were collected and compared.

Results: after one year follow up for all patients we found that patients who underwent laser ablation after resection has less recurrence or progression rates than patients of the other group which was significant statistically. Also they had less postoperative hospital stay and early catheter removal.

Conclusion: laser found that it can decrease the recurrence and progression rates in NMIBC after 1 year follow up, it also found to improve postoperative hematuria and decrease postoperative catheterization time and postoperative hospital stay when compared to conventional TURBT.

Keywords: Non muscle invasive bladder cancer (NMIBC), transurethral resection of bladder tumor (TURBT), laser.

\section{INTRODUCTION:}

Urinary bladder tumors is one of the commonest diseases in genitourinary system. About 549393 new bladder cancer cases have been diagnosed all over the world in 2018, with 199922 cases estimated cancer related death. In other words, bladder cancer accounts around $7 \%$ of new cancer diagnoses and $4 \%$ of new estimated deaths in men ${ }^{(1)}$.

About $75 \%$ of all newly diagnosed cases per year, tumors are confined to the mucosa (Ta, CIS) or submucosa (T1), called nonmuscle-invasive bladder cancer (NMIBC). ${ }^{(2)}$ 
The prevalence of Non-muscle invasive blabber cancer (NMIBC) is higher because of long term survival of most cases, and lower risk of cancer linked mortality compared to muscle invasive bladder cancer (MIBC). ${ }^{(3,4)}$

For non-muscle invasive bladder cancer (NMIBC), conventional transurethral resection of bladder tumor (TURBT) combined with Bacille Calmette-Guerin (BCG) and or intravesical chemotherapy is the standard treatment. ${ }^{(5)}$

Optimization of TURBT procedure could be challenging, because significant morbidities and complications such as obturator nerve reflex, bladder perforation, and intraoperative bleeding that may occur. $^{(6,7)}$

On the other hand, the recurrence rate of NMIBC is still as high as $50-70 \%$, and 5$25 \%$ of cases progress to muscle-invasive bladder tumor after repeated recurrence. ${ }^{(8)}$

Therefore, we need to comprehensively reduce the recurrence rate in NMIBC patients and prolong the time to tumor recurrence. ${ }^{(9)}$

In recent decades, the application of lasers in urological surgeries has undergone great development. Nowadays, lasers are used in various procedures and have become the primary or standard treatment options for many urologic diseases. ${ }^{(10)}$

First attempts to use laser in bladder cancer therapy were published by Staehler and Hofstetter in $1979^{(15)}$. However, first large report on laser use in bladder cancer therapy was published by Beer in $1989^{(11)}$.

Despite promising outcomes, this method was abandoned for years. The reason for that might be possible bowel injury while using deep penetrating $\mathrm{Nd}$ : $\mathrm{YaG}$ laser $^{(12)}$. Nowadays with introduction of new devices, laser resection techniques for bladder tumor are coming back $(13,14)$. Several reports suggest the superiority of the laser method over TURBT, because it seems that a recurrence of cancer after laser treatments is not more frequent than after TURBT and complication rates seem to be lower after modern laser procedures when compared to TURBT (15). In available studies regarding bladder cancer laser resections minimal complications in total were mentioned. Neither deaths, nor acute bleeding has been mentioned in any of the reports ${ }^{(16)}$.

\section{AIM OF THE WORK:}

Evaluation of the value of adding LASER ablation of the tumor bed after resection of the non-muscle invasive transitional cell carcinoma of the urinary bladder.

\section{PATIENTS AND METHODS:}

This is a prospective comparative clinical study (double armed), carried out in the period started form August 2017 to February 2020 aiming to evaluate the value of adding LASER ablation of the tumor bed after resection of the non-muscle invasive transitional cell carcinoma of the urinary bladder.

Our final cohort included 136 patients of non-muscle invasive urinary bladder tumors who were operated and followed up at the Urology Department, Ain Shams University hospitals.

\section{Evaluation of patients:}

All the patients underwent preoperative evaluation before being registered in the study. Inclusion and exclusion criteria were as follows:

Inclusion criteria: Non-muscle invasive transitional cell carcinoma by histopathology examination. And Primary cases. 
Exclusion criteria: Patients with muscle invasive Transitional cell carcinoma, Other histopathological types of bladder tumors rather than TCC, Recurrent cases, Associated Carcinoma in Situ, Patients didn't complete their one year follow up, Patients unfit for anesthesia.

The patients were informed about the nature of the procedure as an adding procedure for management of NMIBC and about all treatment options available. The trial nature of the study was explained to the patients and all signed an informed consent form. The study protocol was approved by local ethical committee of the hospital.

\section{Evaluation of the patients:}

All patients in the study underwent history taking including: Personal history concerning on age, sex, residency, smoking and occupational exposure to risk factors. Medical history (comorbidities, medications).Surgical history.Urologic history (storage symptoms, voiding symptoms, hematuria).

Also all of the patients had routine perioperative laboratory investigations including (renal function, liver function, serum electrolytes, complete blood count, coagulation profile and viral markers), urine analysis and PSA together with radiological investigation (pelvi-abdominal ultrasound, CT urography in high risk patients) and urine cytology.

\section{Patients' characteristics:}

The 136 patients were randomized into two groups, and each consists of 68 patients: Group (A): Underwent transurethral resection of the urinary tumor with conventional protocol (TURBT). Group (B): Underwent transurethral resection of the urinary tumor with conventional protocol with adding a step of LASER ablation of the tumor bed after resection, using high power $980 \mathrm{~nm}$ diode laser

\section{A- Transurethral resection of bladder tumor (TURBT):}

\section{Procedure:}

Antibiotic was given within one hour prior to surgery. In most of cases, the procedure was done under spinal anesthesia. Position: The patient scrubbed in the lithotomy position. A non-conducting irrigation fluid e.g. (Sterile water) is used during the procedure and is placed at a height of about $60-90 \mathrm{~cm}$ from the operating table. The procedure starts by urethrocystoscopy to assess the urethra, prostate size, and, ureteric orifices, other bladder pathology e.g. (stones, and diverticula).Then Check the bladder trigone, posterior wall, dome, and right, left and anterior walls to find all tumors and check the size, shape and site of every tumor. Then start resection of all tumors, if there is multiple tumors we start with tumors at posterior wall or trigone before that at anterior wall to avoid trickling of blood which could obscure vision during rest of resection. Then we put every tumor in a specimen cup with a special cup for the base of the tumor to ensure presence of the muscle layer. Then cauterization of tumor bed to stop bleeding. As the procedure is completed, we turn irrigation inflow off so that the bladder pressure is lowered and check that is there is no bleeding points. At the end of the procedure we irrigate the bladder using Ellik evacuator to ensure no residual tumor chips inside the bladder. Then 3 way 20-22 Fr urethral catheters were applied with slow continuous irrigation of saline until hematuria clears.

\section{B- TURBT followed by laser ablation of tumor bed.}

\section{Procedure:}

All patients underwent the procedure under spinal anesthesia. The laser sheath used was a 23-F continuous irrigation laser scope (Karl Storz, Tuttlingen, Germany). The irrigation fluid used was normal saline 
at room temperature and its height fixed at $60 \mathrm{~cm}$ above the patient. The distal end of the TW fiber is covered by quartz, which is angled by $30^{\circ}$ on the horizontal plane. The laser energy is concentrated at the quartz tip. The TW fibers were operated in a painting fashion. The maximum recommended power to be used for the LTW is $100 \mathrm{~W}$. The procedure had same steps of that of conventional TURBT. Then we add the step of laser ablation of the tumor bed at the end of procedure.

\section{Postoperatively the following data were recorded:}

The patient continues on parenteral antibiotic until discharge (which is usually after 24 hours in laser group and 2-4 days in TURBT group). we used to leave the catheter until the urine is grossly clear without the need for continuous bladder irrigation, then catheter is removed (usually within 24 hours in laser group \& 2-4 days in TURBT group), then patient waits until he voids in a acceptable way before discharge.

Before discharge the following data are recorded: irrigation time, Catheterization time, postoperative hospital stay, Postoperative clot retention or any postoperative complications.

If no muscle presented, T1, High grade/G3 or incomplete resection patient underwent early second look within 2-6 weeks.
If pathology reveal muscle invasion or carcinoma in situ the case is excluded from our study.

Then patients stratified into to low, intermediate or high risk according stage, grade, number and size of tumor.

In low risk patients follow up cystoscopy after 3 months and if negative follow up at 1 years then yearly till 5 years.

In intermediate and high risk patients BCG instillation for 6 weeks then 3 weeks every 3 months till one year, follow up cystoscopy every 3 months were done.

Prior any follow up cystoscopy pelviabdominal ultrasonography, urine analysis, urine cytology (in intermediate and high risk groups) and routine labs is obtained and reassessment of voiding and storage symptoms for every patient.

\section{Statistical methods}

Collected data are regularly submitted in an excel sheet for final statistical analysis. Data management and statistical analysis were done using SPSS vs.25 (IBM, Armonk, New York, United states).Numerical data was summarized as means and standard deviations or medians and ranges. Categorical data was summarized as numbers and percentages. All $\mathrm{P}$ values were two sided. $\mathrm{P}$ values less than 0.05 were considered significant. 


\section{RESULTS:}

Table (1): Tumor characters in both groups.

\begin{tabular}{|c|c|c|c|c|c|c|}
\hline & Laser group & TURT group & \multirow[t]{2}{*}{ Test value } & \multirow[t]{2}{*}{ P-value } & \multirow[t]{2}{*}{ Sig. } \\
\hline & & No. $=68$ & No. $=68$ & & & \\
\hline \multirow{2}{*}{$\begin{array}{l}\text { Size (largest } \\
\text { dimension) }(\mathrm{cm})\end{array}$} & Mean \pm SD & $3.26 \pm 2.20$ & $3.87 \pm 2.26$ & \multirow[t]{2}{*}{$-1.598 \bullet$} & \multirow[t]{2}{*}{0.112} & \multirow[t]{2}{*}{ NS } \\
\hline & Range & $1-11$ & $0.6-10$ & & & \\
\hline \multirow[t]{8}{*}{ Site: } & Dome & $8(11.8 \%)$ & $1(1.5 \%)$ & $5.830 *$ & 0.016 & $\mathrm{~S}$ \\
\hline & Anterior wall & $11(16.2 \%)$ & $13(19.1 \%)$ & $0.202^{*}$ & 0.653 & NS \\
\hline & Left lateral wall & $28(41.2 \%)$ & $33(48.5 \%)$ & $0.743^{*}$ & 0.389 & NS \\
\hline & Right lateral wall & $24(35.3 \%)$ & $31(45.6 \%)$ & $1.496 *$ & 0.221 & NS \\
\hline & Posterior wall & $16(23.5 \%)$ & $15(22.1 \%)$ & $0.042 *$ & 0.838 & NS \\
\hline & Trigone & $10(14.7 \%)$ & $3(4.4 \%)$ & $4.168^{*}$ & 0.041 & $\mathrm{~S}$ \\
\hline & Bladder neck & $4(5.9 \%)$ & $3(4.4 \%)$ & $0.151^{*}$ & 0.698 & NS \\
\hline & Multiple & $3(4.4 \%)$ & $0(0.0 \%)$ & $3.068^{*}$ & 0.080 & NS \\
\hline \multirow[t]{2}{*}{ Number } & Mean \pm SD & $2.07 \pm 1.31$ & $1.46 \pm 0.70$ & \multirow[t]{2}{*}{$3.433^{\bullet}$} & \multirow[t]{2}{*}{0.001} & \multirow[t]{2}{*}{ HS } \\
\hline & Range & $1-5$ & $1-3$ & & & \\
\hline \multirow[t]{2}{*}{ Stage } & $\mathrm{Ta}$ & $46(67.6 \%)$ & $28(41.2 \%)$ & \multirow[t]{2}{*}{ 9.604* } & \multirow[t]{2}{*}{0.002} & \multirow[t]{2}{*}{ HS } \\
\hline & $\mathrm{T} 1$ & $22(32.4 \%)$ & $40(58.8 \%)$ & & & \\
\hline \multirow[t]{2}{*}{ Grade } & Low & $43(63.2 \%)$ & $33(48.5 \%)$ & \multirow[t]{2}{*}{$2.982 *$} & \multirow[t]{2}{*}{0.084} & \multirow[t]{2}{*}{ NS } \\
\hline & High & $25(36.8 \%)$ & $35(51.5 \%)$ & & & \\
\hline
\end{tabular}

$\mathrm{P}>0.05$ : Non significant; $\mathrm{P}<0.05$ : Significant; $\mathrm{P}<0.01$ : Highly significant

$\bullet:$ Independent t-test; *: Chi-square test;

Tumor size in laser group was 1 to $11 \mathrm{~cm}$ with mean of $3.26 \mathrm{~cm}$ and standard deviation 2.20, while in TURBT group was between $0.6 \mathrm{~cm}$ to $10 \mathrm{~cm}$ and the mean was $3.87 \pm 2.26$ standard deviation, which is not statistically significant.The number of tumors in each patient in laser group ranged between 1 to 5 with mean 2.07 and standard deviation of 1.31 , and in TURBT group 1 to 3 tumors in each patient with mean of 1.46 and 0.70 standard deviation. Pvalue is 0.001 which is highly significant.

Table (2): Postoperative data.

\begin{tabular}{|c|c|c|c|c|c|c|}
\hline & Laser group & TURT group & \multirow[t]{2}{*}{ Test value• } & \multirow[t]{2}{*}{ P-value } & \multirow[t]{2}{*}{ Sig. } \\
\hline & & No. $=68$ & No. $=68$ & & & \\
\hline \multirow{2}{*}{ Postop. Irrigation (days) } & Mean \pm SD & $1.00 \pm 0.00$ & $0.98 \pm 0.18$ & \multirow[t]{2}{*}{1.000} & \multirow[t]{2}{*}{0.319} & \multirow[t]{2}{*}{ NS } \\
\hline & Range & $1-1$ & $0.5-1.5$ & & & \\
\hline \multirow[t]{2}{*}{ Hospital stay (days) } & Mean \pm SD & $1.00 \pm 0.00$ & $2.49 \pm 0.76$ & \multirow[t]{2}{*}{-16.057} & \multirow[t]{2}{*}{0.000} & \multirow[t]{2}{*}{ HS } \\
\hline & Range & $1-1$ & $1-4$ & & & \\
\hline \multirow[t]{2}{*}{ Catheter (days) } & Mean \pm SD & $1.34 \pm 0.84$ & $2.78 \pm 1.17$ & \multirow[t]{2}{*}{-8.254} & \multirow[t]{2}{*}{0.000} & \multirow[t]{2}{*}{$\mathrm{HS}$} \\
\hline & Range & $1-4$ & $1-5$ & & & \\
\hline
\end{tabular}

$\mathrm{P}>0.05$ : Non significant; $\mathrm{P}<0.05$ : Significant; $\mathrm{P}<0.01$ : Highly significant $\bullet$ : Independent t-test

Early postoperative data collected include period of irrigation, postoperative hospital stay, and cathetization period. In laser group postoperative irrigation period was always 1 day with mean of 1 day and 0.00 standard deviation, while in TURBT group irrigation time ranged from 0.5 to 1.5 days with mean 0.98 and SD 0.18 days, statistically there is no significance. Postoperative hospital stay in laser group was one day in all patients, in TURBT group hospital stay ranged between 1 to 4 days with mean 2.49 days and 0.76 standard deviation, which is high significant statistically. In laser group postoperative catheterization period ranged between 1 to 4 days with mean of 1.34 days and $0.84 \mathrm{SD}$, whereas in TURBT group 1 to 5 days with mean 2.78 and 1.17 standard deviation, it is also statistically highly significant. 
Table (3): Time to recurrence.

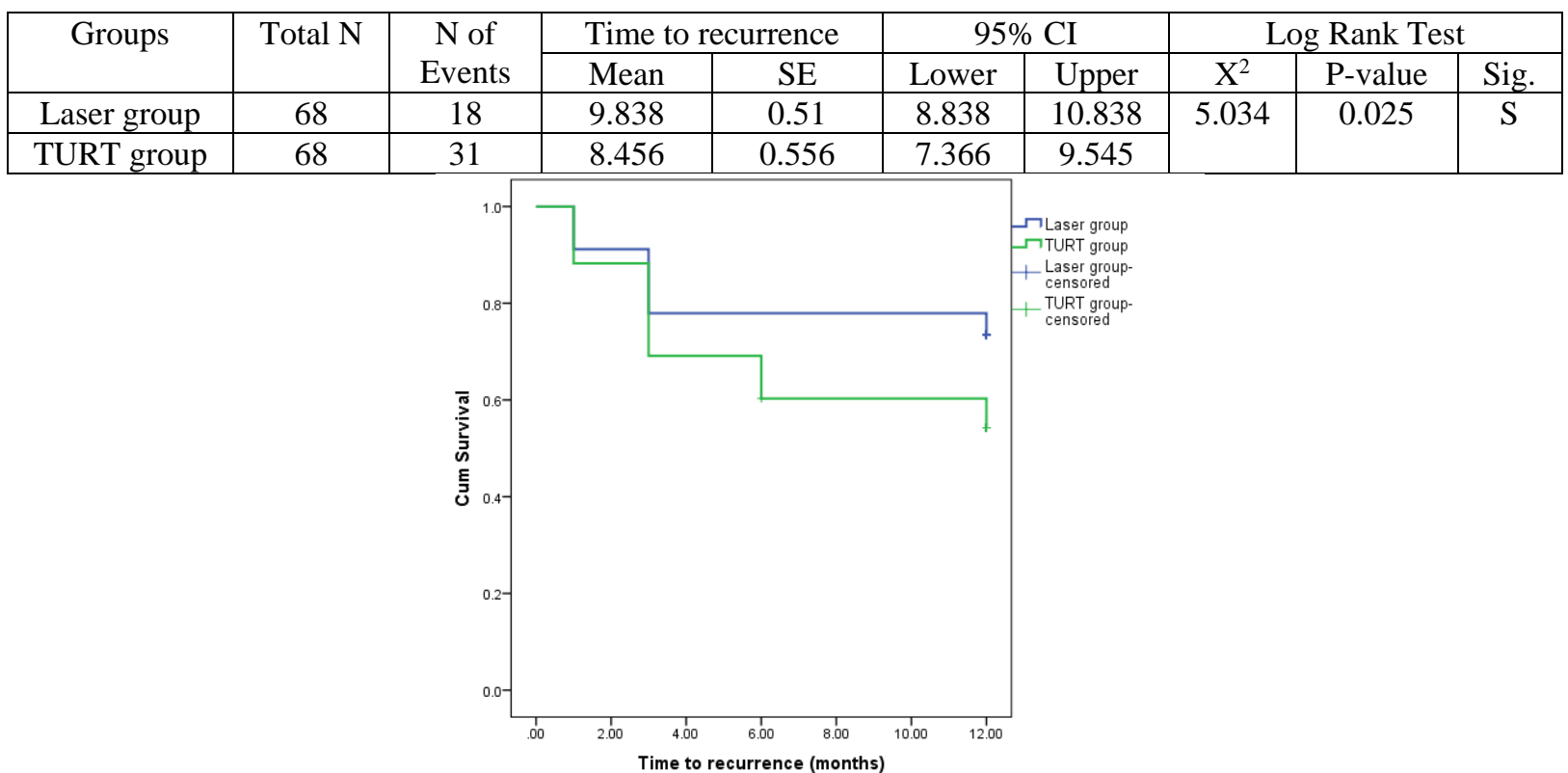

Figure (1): Kaplan Mayer curve for the comparison between the two studied groups regarding time to recurrence

In Laser group there 18 cases with deviation against 8.45 months $\pm 0.055 \mathrm{SD}$ recurrence versus 31 cases in TURBT group, The time to recurrence (survival time) in laser group was 9.83 months \pm 0.51 standard for TURBT group, $\mathrm{P}$-value is 0.025 which is statistically significant.

Table (4): Time to progression.

\begin{tabular}{|c|c|c|c|c|c|c|c|c|c|}
\hline \multirow[t]{2}{*}{ Groups } & \multirow[t]{2}{*}{ Total N } & \multirow{2}{*}{$\begin{array}{c}\mathrm{N} \text { of } \\
\text { Events }\end{array}$} & \multicolumn{2}{|c|}{ Time to progression } & \multicolumn{2}{|c|}{$95 \% \mathrm{CI}$} & \multicolumn{3}{|c|}{ Log Rank Test } \\
\hline & & & Mean & SE & Lower & Upper & $\mathrm{X}^{2}$ & P-value & Sig. \\
\hline Laser group & 68 & 9 & 10.721 & 0.399 & 9.938 & 11.503 & 4.75 & 0.029 & $\mathrm{~S}$ \\
\hline TURBT group & 68 & 20 & 9.941 & 0.461 & 9.038 & 10.845 & & & \\
\hline
\end{tabular}

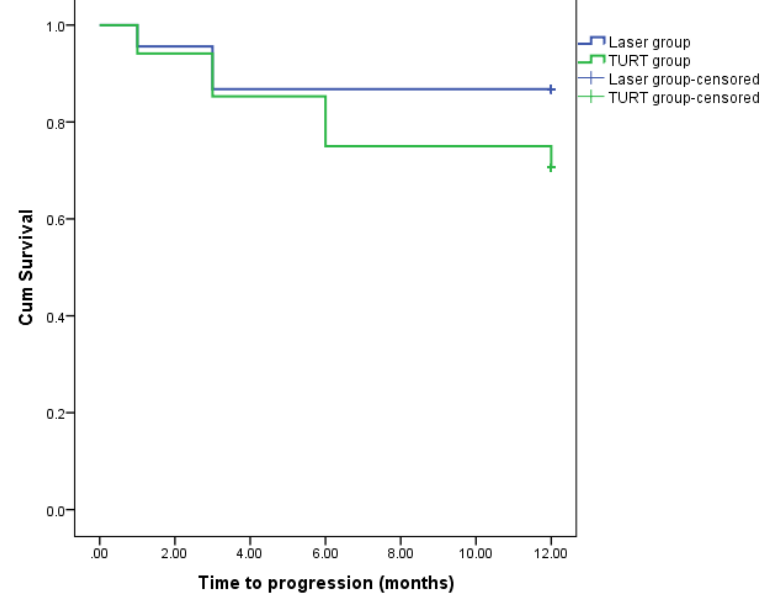

Figure (2): Kaplan Mayer curve for the comparison between the two studied groups regarding time to progression

In Laser group there 9 cases had group, The time to progression (survival progression opposed to 20 cases in TURBT time) in laser group was $10.72 \pm 0.39$ 
months versus 9.94 months $\pm 0.46 \mathrm{SD}$ for TURBT group, which is statistically significant.

\section{DISCUSSION:}

In light of the available literature so far, the main management of non muscle bladder tumors is the transurethral resection using monopolarresectoscope, with intravesical chemotherapy or BCG.

The main problem is high recurrence rate and high progression rate especially in high grade tumors.

Many trials to decrease recurrence and progression rates were done, either by adding a new techniques e.g. enbloc resection, or by postoperative intravesical instilment of chemotherapy or immunotherapy.

In our trial we tried a novel technique by adding a step of laser ablation of the tumor's bed after resection of the tumor by conventional transurethral resection of bladder tumor (TURBT).

No studies or pervious trials found in literature using laser ablation of tumor bed.

We found that we $(26.5 \%)$ recurrent cases in laser group and $(45.6 \%)$, recurrent cases in TURBT group, on other hand there were $(73.5 \%)$ cases had no recurrence in laser group and $(54.6 \%)$ had no recurrence in TURBT group, P-value is 0.021 which is statistically significant.

According progression, in laser group we had (13.2\%) cases compared to 2 $(29.4 \%)$ in TURBT group, while there were $(86.8 \%)$ cases in laser group with no progression and $(70.6 \%)$ in TURBT group, which also statistically significant.

In laser group we had (8.8\%) cases progressed to invasive bladder cancer ended by cystectomy compared to $(23.5 \%)$ patients in TURBT group, on other hand we had $(91.2 \%)$ from laser group continued follow up as NMIBC after one year in comparison to $(76.5 \%)$ in TURBT group.

\section{This also statistically significant:}

In our study we must know its limitations, we had a single center experience, also the limited number of patients, and the short term follow up for 1 year only.

We recommend a larger trials, with multicenter study, and longer period for follow up.

\section{Conclusion:}

Laser ablation of tumor bed after resection is a promising technique to improve outcomes including decrease recurrence and progression rates, and improve postoperative data. More studies are recommended as it is a novel technique with no previous trials.

\section{REFERENCES:}

1. Bray F, Ferlay J, Soerjomataram I, et al. Global cancer statistics 2018: GLOBOCAN estimates of incidence and mortality worldwide for 36 cancers in 185 countries. CA Cancer J Clin. 2018(68):394-424

2. Babjuk M, Burger M, Zigeuner R, Shariat $\mathrm{SF}$, van Rhijn BW, Compérat E, et al. European Association of Urology. EAU guidelines on non-muscle-invasive urothelial carcinoma of the bladder: update 2013. Eur Urol. 2013 Oct; 64(4):639-53.

3. Ferlay J, et al. GLOBOCAN 2012 v1.0: Estimated cancer incidence, mortality and prevalence worldwide in 2012. 2013. 2015

4. Burger M, Catto JW, Dalbagni G, Grossman HB, Herr H, Karakiewicz P, Kassouf W, Kiemeney LA, La Vecchia C, Shariat S, Lotan Y. Epidemiology and risk factors of urothelial bladder cancer. European Urology. 2013; 63(2):234-41.

5. Babjuk M, Böhle A, Burger M, et al. EAU Guidelines on Non-muscle-invasive urothelial carcinoma of the bladder: Update 2016. Eur Urol. 2017; 71:447-61 
6. Muto G, Collura D, Giacobbe A, et al. Thulium: yttriumaluminum-garnet laser for En Bloc resection of bladder cancer: clinical and histopathologic advantages. Urology 2014; 83:851-855.

7. Comploj E, Dechet CB, Mian M, et al. Perforation during TUR of bladder tumours influences the natural history of superficial bladder cancer. World J Urol 2014; 32: 1219- 1223.

8. Ieda T, Muto S, Shimizu F, Taguri M, Yanada S, Kitamura K, et al. Development and Validation of a Novel Recurrence Risk Stratification for Initial Non-muscle Invasive Bladder Cancer in Asia. EBioMedicine. 2016 Oct;12: 98-104.

9. Yang H, Lin J, Gao P, He Z, Kuang X, Li $\mathrm{X}, \mathrm{Fu} \mathrm{H}, \mathrm{Du}$ D. Is the En Bloc Transurethral Resection More Effective than Conventional Transurethral Resection for Non-Muscle-Invasive Bladder Cancer? A Systematic Review and Meta-Analysis. UrolInt 2020; 104:402-409.

10. Pierre SA, Albala DM. The future of lasers in urology. World J Urol 2007; 25:275-283.

11. Beer M, Jocham D, Beer A, Staehler G. Adjuvant laser treatment of bladder cancer:
8 years' experience with the Nd-YAG laser 1064 nm. Br J Urol. 1989; 63: 476-478.

12. Kramer MW, Bach $\mathrm{T}$, Wolters M, et al. Current evidence for transurethral laser therapy of non-muscle invasive bladder cancer. World J Urol. 2011; 29: 433-442.

13. Liu H, Wu J, Xue S, et al. Comparison of the safety and efficacy of conventional monopolar and 2-micron laser transurethral resection in the management of multiple non-muscle invasive bladder cancer. J Int Med Res. 2013; 41: 984-992.

14. Yang D, Xue B, Zang Y, et al. Efficacy and safety of potassium-titanyl- phosphate laser vaporization for clinically non-muscle invasive bladder cancer. Urol J. 2014; 11 : 1258-1263.

15. Herrmann TR, Liatsikos EN, Nagele U, Traxer O, Merseburger AS, European Association of U. [European Association of Urology guidelines on laser technologies]. ActasUrol Esp. 2013; 37: 63-78.

16. Kramer MW, Wolters M, Cash H, et al. Current evidence of transurethral Ho: YAG and Tm: YAG treatment of bladder cancer: update 2014. World J Urol. 2015; 33: 571579. 
كي اورام المثانة البولية الغير متظلظة بالعضلات باستخدام الليزر. هل هناك افضلية عن الطريقة التقليدية

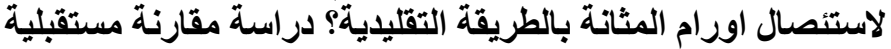

د. سيف الاسلام مصطفى محمد عويضة، ا.د. احمد توفيق حسان، ا.د. أحمد فاروق محمود سالم، ا.د. حسن سيد شاكر

$$
\text { قسم جر احه المساللك البوليه - كليه الطب - جامعه عين شمس }
$$

الخلفية: تعد اورام المثانة البولية الغير متغلغلة بالعضلات من اكثر الاور ام السرطانية شيو عا. وقد تم در استها مر ار ا.

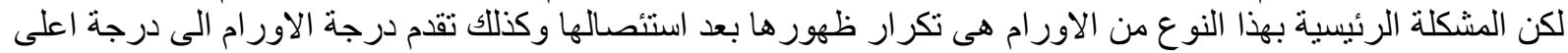

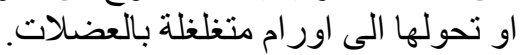

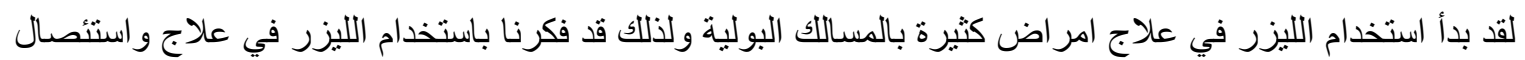
اور ام المثانة البولية ودر اسنة نتائج هذا الاستخدام.

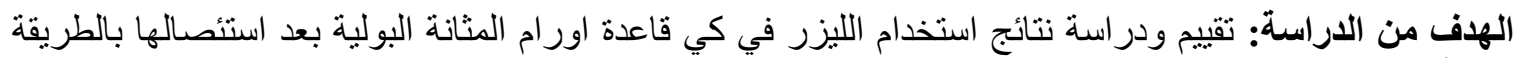

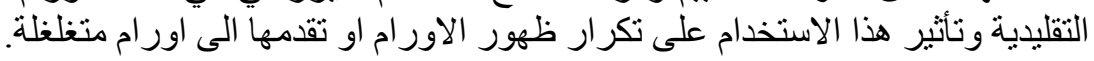

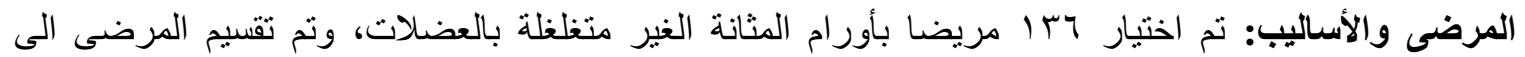

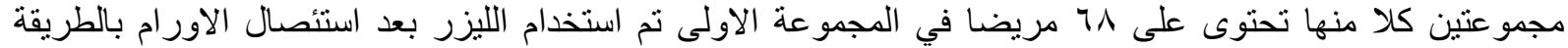

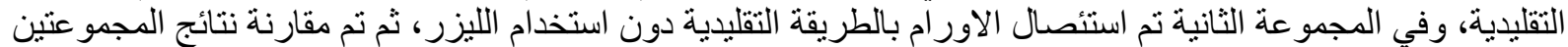
بعد مرور عام كامل باستخدام البر امج الاحصائية المناسبة.

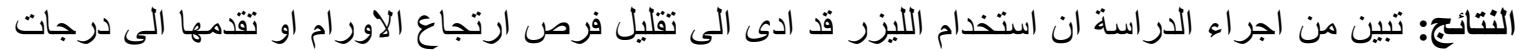

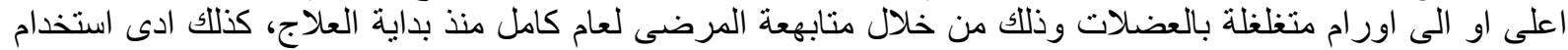

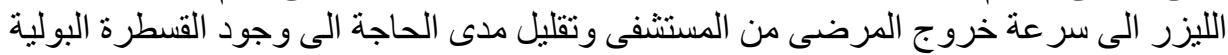

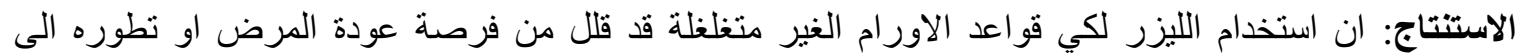
درجات اعلى ونتصح بستخدام هذا النوع من العلاج مع اجر اءع الاء المزيد من الدر اسات عليه 